\title{
Artificial Perches: Ecological and Functional Aspects of its Contribution in the Atlantic Forest
}

Mariana de Andrade Iguatemy ${ }^{1}$ (1) 0000-0003-3820-9339

Joana Alvarez Vilarinhos ${ }^{1}$ (1) 0000-0002-1509-6880

Gabriela Akemi Macedo Oda ${ }^{1,2}$ (1) 0000-0003-3763-5539

Marilena de Menezes Silva Conde 2 (1) 0000-0002-5056-4854

André Scarambone Zaú1 ${ }^{1}$ (D) 0000-0001-6782-351X

\begin{abstract}
Ecological restoration through conventional plantation techniques can create forests with low biodiversity. As such, one way to overcome possible shortcomings of the restoration process is to use nucleation techniques, such as artificial perches. These structures attract the avifauna and increase the deposition of seeds associated with feces or bird regurgitation. Seed rain and seedlings regeneration were monitored under artificial perches and control areas in a degraded area of Rio de Janeiro, RJ, Brazil. In this study, 46 morphospecies of seeds were identified. Under the perches, greater abundance and richness of seeds were found with certain ecological and functional traits that support the role of artificial perches as a biological diversity core. Seedling establishment was low under the perches and control areas. This suggests that integrated actions to improve soil conditions should be applied to enhance seedling establishment.
\end{abstract}

Keywords: ecological restoration, nucleation, seed rain.

\section{INTRODUCTION}

Ecological restoration is the assisting process of restoration of a degraded, damaged or destroyed ecosystem (SER, 2017). It is a deliberate activity that initiates or accelerates environmental recovery, with respect to its health, integrity and sustainability. In this way, restoration actions aim to develop ecologically viable communities, protecting and promoting the natural change within the ecosystem, as well as sustainability and resiliency (SER, 2017). Degradation occurs when the natural habitat conversion leads to loss of adaptability to chemical, physical and biological characteristics (Ibama, 1990; Lamb et al., 2005).

Most of the areas originally covered by Atlantic Forest were destroyed as a result of land conversion into rural areas and urban expansion (Ribeiro et al., 2009). The Atlantic Forest is composed of a series of ecosystems along the Brazilian east coast, ranging from mangroves and restingas to altitude forests and rugged terrain (Mittermeier, 2004). The high rate of biological diversity and endemic species, coupled with high level of degradation, make this environment one of the top hotspots for biodiversity conservation in the world (Laurance, 2009; Myers et al., 2000). The Atlantic Forest currently has about $15.2 \%$ of its original vegetation cover, considering the native forest remnants larger than 3 ha (SOS Mata Atlântica \& Inpe, 2018). These remnants, in most cases, are insufficient for the conservation of many rare species, especially those that require large areas (Ribeiro et al., 2009).

In this scenario, the state of Rio de Janeiro, located in Southeastern Brazil, suffers from forest cover loss, leading to instability of the slopes, which in turn leads to erosion and landslides (Figueiró \& Coelho Netto, 2007). Important areas such as Maciços do Gericinó-Mendanha, Tijuca and Pedra Branca suffer heavy environmental degradation because of

\footnotetext{
${ }^{1}$ Universidade Federal do Estado Rio de Janeiro (UniRio), Rio de Janeiro, RJ, Brasil
}

${ }^{2}$ Universidade Federal Rural do Rio de Janeiro (UFRRJ), Seropédica, RJ, Brasil 
deforestation and disordered occupation on their slopes (Barbosa \& Rodrigues, 2017).

Environmental degradation can cause losses in the structure and diversity of species, creating temporary or permanent reduction in the productive capacity of an ecosystem (Moraes et al., 2010). The process of forest recovery may vary; more stable areas tend to recover quickly, while in other areas it may take centuries (Bechara et al., 2016). This is closely linked to the concept of ecological resilience of the area (Moraes et al., 2010). The process of succession is often self-establishing, but in cases where degradation is very intense, it is necessary to intervene with long-term strategies (Kageyama et al., 2008; Sansevero et al., 2017).

Alternative techniques of ecological restoration are an effective alternative to overcome some of the shortcomings of conventional planting methods used in ecological restoration projects (Bechara et al. 2007; Franks 2003; Yarranton \& Morrison, 1974). These techniques aim to create microhabitats and nuclei that act as facilitators for arrival of species and survival of all life forms, accelerating ecological succession and increasing diversity of adjacent areas (Bechara et al., 2016; Reis et al., 2003).

One nucleation technique is the construction of artificial perches that can be used by birds for foraging, resting and shelter. This causes a greater deposition of zoochorous seeds associated with stool and regurgitation (Holl, 1998; Stiles \& White, 1986) or the unintentional fall of seeds under these perches. This is one of the best strategies to connect forest fragments, since it promotes an ecological flux from the animal-plant interactions, and has the potential to connect landscape units in different directions (Tres \& Reis, 2009). However, the efficiency of this technique is still not clear; even if the perches contribute in attracting birds and enriching seed rain, little is known about the ecological and functional traits of these seeds and whether the arrival of propagules would be effective in plant establishment (Helleman et al., 2012; Holl, 1998; Reid \& Holl, 2013).

Based on the considerations aforementioned, this study aims to quantify and qualify the propagule arrival and the initial seedling establishment with the use of artificial perches and without perches (control) in an area of Atlantic Forest slope, under restoration process. The specific objectives were: (1) to identify morphospecies through seeds; (2) to quantify the abundance and richness, (3) to assess ecological and functional traits of the morphospecies, (4) to quantify the seedling abundance; and (5) to evaluate the results of the method at different distances (30 and $60 \mathrm{~m}$ ) of the forest remnant.

\section{MATERIAL AND METHODS}

\subsection{Study area}

The Inhoaíba mountain is located near the Pedra Branca Massif, in the West Zone of Rio de Janeiro, RJ (Figure 1). The climate is tropical hot and humid, with annual average rainfall of $1187 \mathrm{~mm}$ and rainfall seasonally defined with small water deficiency between the months of July and October (Togashi et al., 2012). The mean annual temperature is $26^{\circ} \mathrm{C}$ (Oliveira et al., 1980; Rio de Janeiro, 2000). The original vegetation of the study area is Dense Ombrophylous Forest (Mata Atlântica strictu sensu), mainly submontane forest (Veloso et al., 1991). The area already underwent some restoration attempts, without success. The area is covered by a mosaic of vegetation in initial and intermediate stages of succession and presents moderate susceptibility to erosion.

\section{Inhoaíba's Reforest Location Map, Rio de Janeiro, Brazil}

(a)

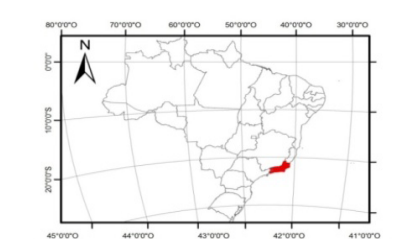

(b)

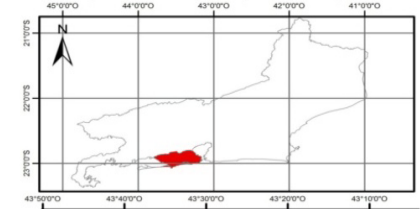

(c)
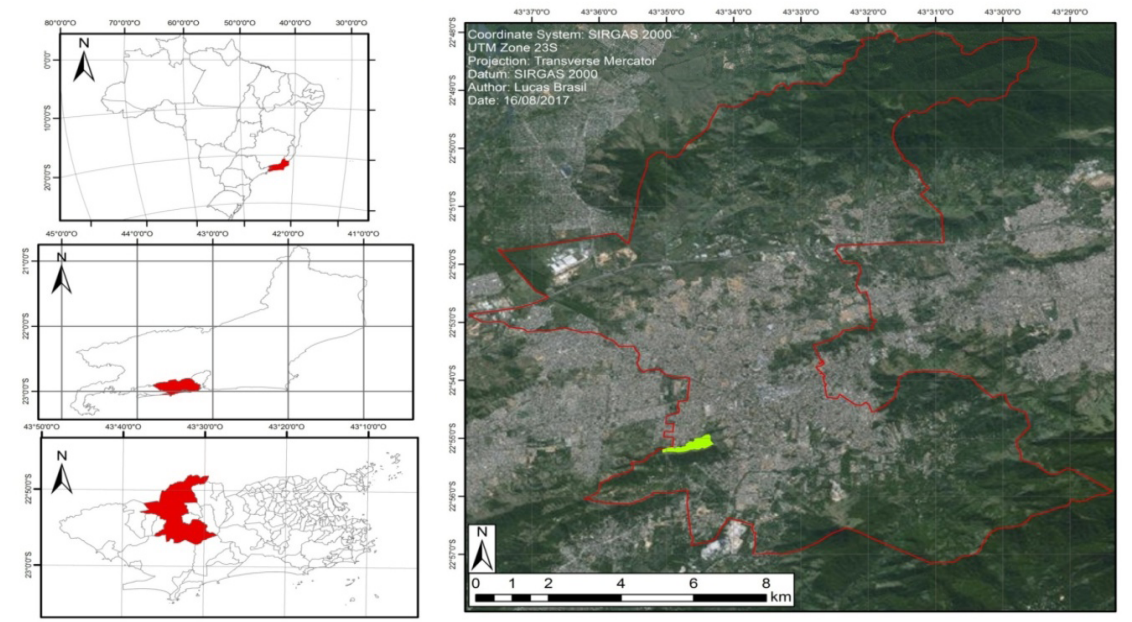

Figure 1. Location of the Rio de Janeiro state (a), Rio de Janeiro municipality (b), Campo Grande neighborhood (c), and reforestation area in Serra de Inhoaíba (d). 


\subsection{Installation of artificial perches and sampling points}

Ten artificial perches were mounted, with $30 \mathrm{~m}$ in-between. Five were arranged $30 \mathrm{~m}$ away from the reforestation area and the other five at $60 \mathrm{~m}$. These perches were made with $7 \mathrm{~m}$ high bamboo stems. In each stem, circular frame sticks $(1 \mathrm{~m} \times 30 \mathrm{~mm})$ were fixed in the heights of $3.5 \mathrm{~m}$ and $5.5 \mathrm{~m}$, using ropes and epoxy mass. Each perch was buried $1 \mathrm{~m}$ deep with the use of an auger, to avoid tipping the structure.

Below each perch two square collectors of $0.50 \times 0.50 \mathrm{~m}$ were allocated, made with wire and mousseline fabric, for a total catch area of $0.50 \mathrm{~m}^{2}$. Still below the perches, $1.0 \times 0.50 \mathrm{~m}$ plots were allocated for the monitoring of the seed germination that eventually reached the site. In each subplot of $0.50 \times 0.50 \mathrm{~m}$, the following treatments were carried out: one with grass management and the other without management (Figure 2). In the management treatment, all grass cover was removed in each survey. Five meters from each perch, a seed collector that was considered the control was installed.

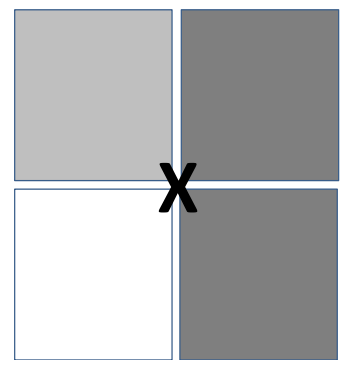

Figure 2. Scheme of seedling sampling and seed rain.

The " $\mathrm{X}$ " in black represents the artificial perch; in light gray: seedling sampling with grass management; white: seedling sampling without grass management, dark gray: seed rain sampling.

\subsection{Monitoring of seed rain and seedling regeneration}

The seed rain and seedling establishment were monitored for six months (April to September 2015), in ten expeditions. The collected seeds were stored in paper bags and dried in the laboratory in a stove for 48 hours or until they had a constant dry weight.

The seeds were sorted and identified using a stereoscopic microscope then counted and assigned to morphospecies. The following functional and ecological traits were assessed for each morphospecies: successional stage (tolerant and intolerant to shade) (Whitmore, 1990), dispersion syndrome (anemochorous, autochorous and zoochorous) (Van der Pijl,
1982) liana or grass (Radford et al., 1974), and origin (exotic, native or naturalized) (Moro et al., 2012). Seed mass was weighted on an scale (to $\mathrm{mg}$ ), and the mean mass of each morphospecies was calculated and classified as light (mean mass $<0.001 \mathrm{~g})$, medium $(0.001 \mathrm{~g}<$ mean mass $<0.015 \mathrm{~g})$ or heavy (mean mass $\geq 0.015 \mathrm{~g}$ ).

Seedlings using aluminum blades with individual numbers were monitored. In each visit, death and entry of new individuals were recorded.

\subsection{Statistical analyses}

A cluster analysis was performed using Euclidean distances with complete linkage between the areas, on a presenceabsence matrix with seed richness data. Then the richness and abundance of seed morphospecies were compared through a $t$-test, when the assumptions for parametric analysis were met. In this case, the areas with perches at $30 \mathrm{~m}$ and $60 \mathrm{~m}$ of the remnant were compared with the control areas. The Kolmogorov-Smirnov tests for non-parametric distributions were used. In the seedlings case, and when the parametric assumptions were respected, they were compared with an Anova factorial test with two fixed factors (presence of perches and grass management), using the Tukey's posterior test. When these assumptions were not met, the non-parametric Friedman analysis was used. These analyses were performed using the Statistica 7 software (StatSoft, 2004). All grass species were excluded from seed richness and abundance analysis because these seeds were deposited in the collectors by the wind, a common process in graminoid fields such as the experiment area.

\section{RESULTS AND DISCUSSION}

\subsection{Seed rain}

In total, this study found 27,700 seeds of 46 morphospecies from 20 families (Table 1). All 46 morphospecies were under the perches and 21 morphospecies at the control groups. The Poaceae family contributed with 22,949 seeds ( $82 \%$ ), mainly grasses dispersed by wind. The high number of grass seeds deposited over the six months may be related to the predominant matrix characteristic ("Colonião" grass - Urochloa maxima (Jacq.) RDWebster) and the collection period in the dry season, when anemochorous species are favored (Howe \& Smallwood, 1982). Thus, we analyzed the data excluding this family, and from the remaining 4,750 seeds, 4,238 (89\%) were collected under the perches and 512 seeds $(11 \%)$ in the controls. 
Table 1. Seed species deposited on perches and control groups in São Jorge, Rio de Janeiro, RJ. The species were classified according to the successional stage, dispersion, habit and origin: intolerant (I), shade tolerant (T), zoochorous (Z), autochorous (Aut), anemochorous (Ane), shrub (Arb), arboreal (Arv), herbaceous (H), subshrub (Sarb), liana (L), native (N), naturalized (Nz), exotic (E).

\begin{tabular}{|c|c|c|c|c|c|}
\hline Family & Species & Succession & Dispersion & Habit & Origin \\
\hline Amaranthaceae & Amaranthaceae & I & & & $\mathrm{N}$ \\
\hline Anacardiaceae & Schinus terebinthifolius Raddi & I & $\mathrm{Z}$ & Arb/Arv & $\mathrm{N}$ \\
\hline \multirow[t]{7}{*}{ Asteraceae } & Bidens pilosa $\mathrm{L}$. & I & $\mathrm{Z}$ & $\mathrm{H}$ & $\mathrm{Nz}$ \\
\hline & Mikania stipulacea Willd. & I & Ane & $\mathrm{H}$ & $\mathrm{N}$ \\
\hline & Parthenium hysterophorus L. & I & Aut & $\mathrm{H}$ & $\mathrm{Nz}$ \\
\hline & Helianthus annuus L. & I & Z/Aut & $\mathrm{H}$ & $\mathrm{E}$ \\
\hline & Synedrellopsis grisebachii & I & Z/Aut & $\mathrm{H}$ & $\mathrm{Nz}$ \\
\hline & Trichogonia sp & I & & Arb/Sarb & $\mathrm{N}$ \\
\hline & $\begin{array}{l}\text { Hypocaeris radicata ou Porophyllum } \\
\text { ruderale }\end{array}$ & I & Z/Aut & $\mathrm{H}$ & $\mathrm{E}$ \\
\hline Caryophyllaceae & Silene gallica L. & I & Ane/Aut & $\mathrm{H}$ & $\mathrm{Nz}$ \\
\hline Chloranthaceae & Hedyosmum cf. & & Z & Arb/Arv & $\mathrm{N}$ \\
\hline Eritroxylaceae & Erythroxylum sp. & & $\mathrm{Z}$ & Arb/Arv & $\mathrm{N}$ \\
\hline \multirow[t]{5}{*}{ Fabaceae } & Crotalaria mucronata Desv. & I & Z/Aut & $\mathrm{H}$ & $\mathrm{N}$ \\
\hline & Dalbergia nigra (Vell.) Allemão ex Benth. & I & Ane & Arv & $\mathrm{N}$ \\
\hline & Crotalaria anagyroides Kunth. & I & Z/Aut & Arb & $\mathrm{N}$ \\
\hline & Aeschynomene indica L. ou Calopogonium & I & Z/Aut & $\mathrm{H}$ & \\
\hline & Fabaceae & & & & \\
\hline Lamiaceae & Leucas martinicensis (Jacq.) R. Br. & I & Aut & $\mathrm{H}$ & $\mathrm{Nz}$ \\
\hline Meliaceae & Guarea macrophylla Vahl & $\mathrm{T}$ & $\mathrm{Z}$ & Arv & $\mathrm{N}$ \\
\hline Myrtaceae & Campomanesia & $\mathrm{T}$ & $\mathrm{Z}$ & Arb/Arv & $\mathrm{N}$ \\
\hline Papillionaceae & Desmodium adscendens (Sw). DC. & I & $\mathrm{Z}$ & Sarb & $\mathrm{Nz}$ \\
\hline Passifloraceae & Turnera subulata Sm. & I & Z/Aut & Arb & $\mathrm{N}$ \\
\hline Piperaceae & Piper cernuum ou divaricatum & I & Z & Arb & $\mathrm{N}$ \\
\hline \multirow[t]{7}{*}{ Poaceae } & Axonopus scoparius (Flügge) Kuhlm & I & Ane & $\mathrm{H}$ & $\mathrm{N}$ \\
\hline & Brachiaria plantaginea (Link) Hitchc & I & Ane & $\mathrm{H}$ & $\mathrm{E}$ \\
\hline & Chloris gayana Kunth & I & Ane & $\mathrm{H}$ & $\mathrm{N}$ \\
\hline & Echinolaena inflexa (Poir.) Chase & I & Z/Ane & $\mathrm{H}$ & $\mathrm{N}$ \\
\hline & Pennisetum pedicelatum Trin. & I & Ane & $\mathrm{H}$ & $\mathrm{N}$ \\
\hline & Hyparrhenia rufa (Nees) Stapf. & & & $\mathrm{H}$ & $\mathrm{E}$ \\
\hline & $\begin{array}{l}\text { Sorghum arundinaceum ou Chloris } \\
\text { polydactyla (L.) Sw }\end{array}$ & I & Ane & $\mathrm{H}$ & $\mathrm{N}$ \\
\hline \multirow[t]{3}{*}{ Rubiaceae } & Alseis sp. & & & Arb/Arv & $\mathrm{N}$ \\
\hline & Psychotria sp. & & $\mathrm{Z}$ & & $\mathrm{N}$ \\
\hline & Psychotria ou Palicourea & & $\mathrm{Z}$ & Arb/Arv & $\mathrm{N}$ \\
\hline Rutaceae & Dictyoloma vandellianum A.Juss. & & Ane & Arv & $\mathrm{N}$ \\
\hline \multirow[t]{3}{*}{ Salicaceae } & Casearia sylvestris $\mathrm{Sw}$ & I & $\mathrm{Z}$ & Arb & $\mathrm{N}$ \\
\hline & Casearia commersoniana Cambess. & I & $\mathrm{Z}$ & Arb & $\mathrm{N}$ \\
\hline & Casearia (oblongifolia ou selloana) & & $\mathrm{Z}$ & Arb/Arv & $\mathrm{N}$ \\
\hline \multirow[t]{2}{*}{ Solanaceae } & Solanum americanum Mill. & I & $\mathrm{Z}$ & $\mathrm{H}$ & $\mathrm{N}$ \\
\hline & Solanum paniculatum L. & I & $\mathrm{Z}$ & Arb & $\mathrm{N}$ \\
\hline Vitaceae & Cissus cf. erosa & I & $\mathrm{Z}$ & $\mathrm{L}$ & $\mathrm{N}$ \\
\hline \multirow[t]{6}{*}{ Undetermined } & undetermined 1 & & & & \\
\hline & undetermined 2 & & & & \\
\hline & undetermined 3 & & & & \\
\hline & undetermined 4 & & & & \\
\hline & undetermined 5 & & & & \\
\hline & undetermined 6 & & & & \\
\hline
\end{tabular}


In a study in the closest adjacent forest fragment, Muler (2014) reported only three species found in our study (Casearia commersoniana Cambess., Dalbergia nigra (Vell.) Allemão ex Benth. and Schinus terebinthifolius Raddi). This suggests that the seeds come from more distant fragments, highlighting that this type of contribution can create greater species richness and genetic diversity, which are important issues and great challenges for restoration projects (Lamb et al., 2005; Zuchi et al., 2017).

We compared our results to those of Vicente et al. (2010), a study carried out in the Atlantic Forest of southern Brazil, and we found that seed abundance was eight times higher, and richness was doubled. This suggest that our study area shows great potential for seed arrival. Other studies in southern Brazil found 21,864 seeds of 51 morphospecies (Tomazi et al., 2010) and, in Porto Rico, 21,507 seeds of 28 morphospecies (Shiels and Walkers, 2003). These studies collected seeds for more than one year.

In the clustering analysis, this study observed one group formed by the control sample, and other formed by the perches, with the exception of one perch sample point (p10) (Figure 3). However, there was no clustering when the distance of the sampling in relation to the fragment edge was considered (Figure 3). That is, the perch distance from the forest edge was not a main factor in the seed species composition. In a similar experiment, in pasture near a fragment of Atlantic Forest in the state of Paraná, Zwiener et al. (2014) reported significant differences in the seed rain richness on isolated trees and artificial perches installed at $10 \mathrm{~m}$ and $300 \mathrm{~m}$ from the forest edge, with greater species richness at more remote perches. Dias et al. (2014) did not find difference in the seed species composition in perches installed between $5 \mathrm{~m}$ and $35 \mathrm{~m}$ from the fragment edge, a similar result to the one observed in this study.

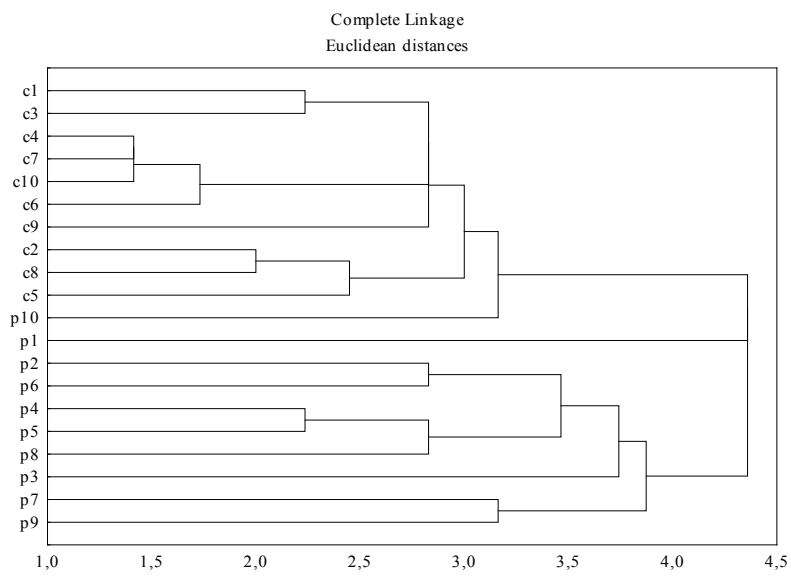

Figure 3. Dendrogram of dissimilarity using Euclidean distance with complete linkage for perches and controls samples at different distances in relation to forest fragment (P1 to $\mathrm{P} 5$ and $\mathrm{C} 1$ to $\mathrm{C} 5$ to $30 \mathrm{~m}$ and $\mathrm{P} 6$ to $\mathrm{P} 10$ and $\mathrm{C} 6$ to $\mathrm{C} 10$ to $60 \mathrm{~m}$ ) in Serra de Inhoaíba, Rio de Janeiro, Brazil.
Abundance under the perches was nine times greater than the one observed in the control group (Perches, median: 448.5; Control: $53 ; \mathrm{Z}=3.3, p \leq 0.00)$. The richness was also higher in perches (Perches: $13.0 \pm 2.44$, Control: $4.9 \pm 2.18$, $\mathrm{F} \leq 60.94, p \leq 0.00$, Figure 4 ). This difference was observed in other studies with artificial perches, confirming the richness and abundance increase hypothesis (Almeida et al., 2016; Bechara, 2007; Bochese et al., 2008; Dias et al., 2014; Guidetti et al., 2017, Oliveira et al., 2018).

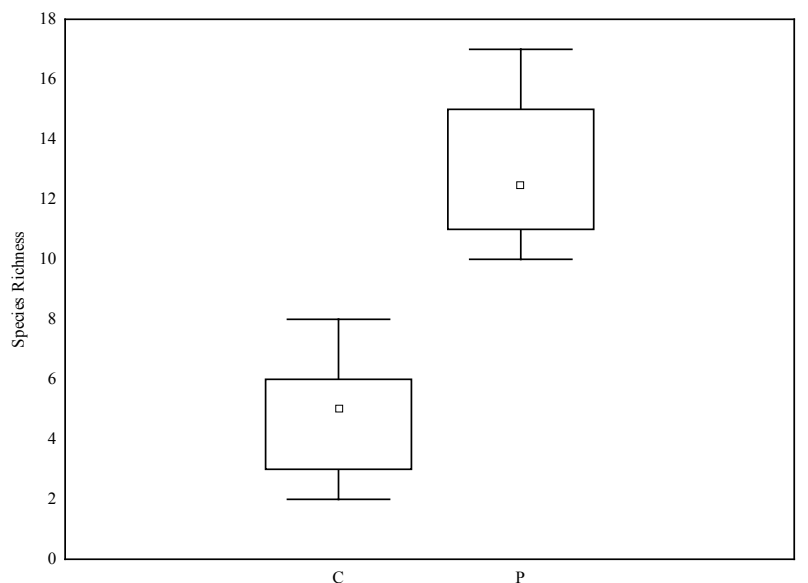

Figure 4. Box plot representing the richness of seed rain on perches (P) and the control group (C). Mean, standard deviation and confidence interval are plotted.

Regarding the ecological and functional traits, we observed a difference between seeds under perches and the control sample (Table 2), evidence of the potential of perches to contribute as biological diversity nuclei (Reis et al., 2003; Tres \& Reis, 2009). We only found shade-tolerant species under perches. Shadetolerant species generally have longer life cycle and are typically part of forest in more advanced successional stages (Durigan et al., 2008). In the tree species seeds case, 104 (23\%) arrived under perches, while only one $(0.19 \%)$ arrived in the control group. In restoration projects, trees are an important component of soil cover, as they increase environmental heterogeneity and create microhabitats for germination, consequently favoring forest regeneration (Brown \& Lugo, 1994; Melo \& Durigan, 2007). We recorded $6 \%$ heavy seeds under perches and $0.8 \%$ in the control group. Large-sized seeds may represent higher establishment capacity, but can also represent arrival difficulties in areas in regeneration due the disappearance of potential dispersers (Dalling \& Hubbell, 2002; Lamb et al., 2005). Under the perches, this study found that $88.1 \%$ of the seeds were native while in the control group this percentage was $53.3 \%$ (Table 2). The high number of native species in a seed bank may strengthen the vegetation recovery potential (Silva-Weber et al., 2012). 
Table 2. Quantitative data for successional stage, origin and seeds habit collected in controls and perches.

\begin{tabular}{lccccccccccc} 
& \multicolumn{3}{c}{ Successional stage } & \multicolumn{3}{c}{ Origin } & & \multicolumn{3}{c}{ Habit } \\
& Total & Intolerant & Tolerant & Native & Exotic & Naturalized & Herbaceous & Shrub & Tree \\
Controls & 512 & 473 & 0 & 273 & 0 & 194 & 292 & 180 & 2 \\
\hline Perches & 4238 & 4013 & 96 & 3735 & 17 & 411 & 607 & 3236 & 157 \\
\hline
\end{tabular}

We recorded 1,233 zoochorous seeds under perches and only eleven in the control group. In a similar experiment, also in Rio de Janeiro, Dias et al. (2014) found in 21 collection days, 118 times more zoochorous seeds in perches than in the control group. Artificial perches formed new seed nuclei within the pasture area, acting as nucleating points in the degraded area, facilitating zoochorous seed arrival (Almeida et al., 2016; Tomazi \& Castellani, 2016). Zoochorous seeds under perches represent mostly arboreal life forms, suggesting that the birds with an arboreal food habit bring seeds of nearby forest fragments (Tres \& Reis, 2009). Such facts demonstrate that perches can serve as ecological trampolines connecting landscape elements (Tres \& Reis, 2009).

\subsection{Seedlings}

The seedling numbers recorded throughout this experiment were small, with low establishment numbers and high death rates for all treatment types. There were no significant differences of these variables between perches and the control sample, or with and without grass management (Table 3), because of the low values observed. In general, invasive grasses with populations in disequilibrium (high abundance and density) may be an exclusion factor for seed germination (Moraes et al., 2010; Parker, 1997). However, our results suggest that establishment and mortality are not caused by grass competition, but rather to inadequate conditions for seed germination and seedling establishment. Factors such as water stress, mechanical damage, herbivory, pathogens, soil compaction, among others, affect seedling establishment and survival in pasture environments (Bocchese et al., 2008).

Similar results with low seed germination and seedling establishment were observed in other experiments with perches in tropical pastures (Almeida et al., 2016; Heelemann et al., 2012; Holl, 1998), suggesting that factors such as soil degradation can interfere in the germination of the dispersed seeds and in the survival of germinated individuals. Holl (1998) observed in an experiment with perches in Costa Rica that the number of seedlings was extremely low and did not differ significantly between habitat types (open pasture and perches). Although the perches help seed arrivals in open areas, due to the conditions of these sites, they have little chance of surviving (Almeida et al., 2016; Heelemann et al., 2012; Reid \& Holl, 2013). This suggests that seed arrival does not guarantee the seedlings establishment and that the tropical forests recovery demands integrated actions, with issues still remaining to be solved.

Table 3. Mortality and establishment of seedlings in perch and control plots with and without grass management.

\begin{tabular}{llcccc}
\multicolumn{1}{c}{ Treatment } & Mortality & Friedman & \multicolumn{2}{c}{ Establishment Fatorial Anova } \\
Perches & Management & $0.35 \pm 0.26$ & $2.41 ; p=0.49$ & $1 \pm 4.37$ & Factor 1: treatment $\mathrm{F}=0.38 ; p=0.54$ \\
\cline { 1 - 4 } & Without Management & $0.3 \pm 0.2$ & & $2.5 \pm 1.23$ & Factor 2: management $\mathrm{F}=0.44 ; p=0.51$ \\
\multirow{2}{*}{ Control Plots } & Management & $0 \pm 0$ & & $0.1 \pm 0.32$ & Interaction: $\mathrm{F}=0.38 ; p=0.54$
\end{tabular}

\section{CONCLUSION}

Artificial perches increased the morphospecies richness and abundance in the seed rain in the Serra de Inhoaíba, Rio de Janeiro, RJ, Brazil. Forest fragment distance $(30 \mathrm{~m}$ and $60 \mathrm{~m}$ ) did not influence seed arrival. Artificial perches assist the dispersion of zoochorous, large-seeded and shade-tolerant species, important ecological and functional traits in the restoration of communities' ecological processes. However, these species showed low seedling establishment and high seedling mortality. Other ecological restoration techniques that complement artificial perches should be used in order to overcome the obstacles after dispersal. Integrated strategies that aim to increase seedling establishment and improve soil quality can help in the catalysis of this process.

\section{ACKNOWLEDGEMENTS}

To the teams at Secretaria de Meio Ambiente of the city of Rio de Janeiro, the Projeto Mutirão and the Fundação Bio-Rio for the financial and logistical support. To the members of the Laboratório de Ecologia Florestal of Universidade Federal do Estado Rio de Janeiro and the Reflora project for the technical and logistical support in 
all steps of this research. To the researchers Dr. Richieri Sartori for the contribution in project design and Dr. Arno F. N. Brandes, for the review of the manuscript.

\section{SUBMISSION STATUS}

Received: 20 June 2018

Accepted: 30 Mar 2019

Associate editor: Rodrigo Studart Corrêa

(D) 0000-0002-9422-2629

\section{CORRESPONDENCE TO}

\section{Mariana de Andrade Iguatemy}

Universidade Federal do Estado do Rio de Janeiro (UniRio), Av. Pasteur, 296, CEP 22290-240, Rio de Janeiro, RJ, Brasil e-mail: m_iguatemy@hotmail.com

\section{REFERENCES}

Almeida A, Marques MCM, Ceccon-Valente M, Vicente-Silva J, Mikich SB. Limited effectiveness of artificial bird perches for the establishment of seedlings and the restoration of Brazil's Atlantic forest. Journal for Nature Conservation 2016; 34: 24-32. 10.1016/j. jnc.2016.08.007

Barbosa DR, Rodrigues NM. Dualidade conservação $\times$ degradação no patrimônio geomorfológico do Maciço do Gericinó-Mendanha: uma análise da vertente voltada para o Rio de Janeiro. In: Peres Filho A, Amorim RR, editors. Os desafios da geografia física na fronteira do conhecimento. Campinas: Unicamp; 2017. p. 3299-3303. 10.20396/sbgfa.v1i2017.2598

Bechara FC, Campos Filho EM, Barretto KD, Gabriel VA, Antunes AZ, Reis A. Unidades demonstrativas de restauração ecológica através de técnicas nucleadoras de biodiversidade. Revista Brasileira de Biociências 2007; 5(1): 9-11.

Bechara FC, Dickens SJ, Farrer EC, Larios L, Spotswood EN, Mariotte P, Suding KN. Neotropical rainforest restoration: comparing passive, plantation and nucleation approaches. Biodiversity and Conservation 2016; 25(11): 2021-2034. 10.1007/s10531-016-1186-7

Bocchese RA, Oliveira AKM, Fávero S, Garnés SJS, Laura VA. Chuva de sementes e estabelecimento de plântulas a partir da utilização de árvores isoladas e poleiros artificiais por aves dispersoras de sementes, em área de cerrado, Mato Grosso do Sul, Brasil. Revista Brasileira de Ornitologia 2008; 16:(3): 207-213.

Brown S, Lugo AE. Rehabilitation of tropical lands: a key to sustaining development. Restoration Ecology 1994; 2(2): 97-111. 10.1111/j.1526-100X.1994.tb00047.x

Dalling JW, Hubbell SP. Seed size, growth rate and gap microsite conditions as determinants of recruitment success for pioneer species. Journal of Ecology 2002; 90(3): 557-568. 10.1046/j.13652745.2002.00695.x

Dias CR, Umetsu F, Breier TB. Contribuição dos poleiros artificiais na dispersão de sementes e sua aplicação na restauração florestal. Ciência Florestal 2014; 24(2): 501-507. 10.5902/1980509814590

Durigan G, Bernacci LC, Franco GADC, Arbocz GF, Metzger JP, Catharino ELM. Estádio sucessional e fatores geográficos como determinantes da similaridade florística entre comunidades florestais no planalto Atlântico, estado de São Paulo, Brasil. Acta Botanica Brasilica 2008; 22(1): 51-62. 10.1590/S0102-33062008000100007

Figueiró AS, Coelho Netto, ALC. Análise da variabilidade térmica em zonas de bordas florestais com interface urbana no maciço da Tijuca Rio de Janeiro-RJ. Ciência e Natura 2007; 29(2): 173-186. $10.5902 / 2179460 X 9892$

Franks SJ. Facilitation in multiple life-history stages: evidence for nucleated succession in coastal dunes. Plant Ecology 2003; 168(1): 1-11. 10.1023/A:1024426608966

Guedes MC, Melo VA, Griffith JJ. Uso de poleiros artificiais e ilhas de vegetação por aves dispersoras de sementes. Ararajuba 1997; 5(2): 229-232.

Guidetti BY, Amico GC, Dardanelli S, Rodriguez-Cabal MA. Artificial perches promote vegetation restoration. Plant Ecology 2016; 217: 935-942. 10.1007/s11258-016-0619-4

Heelemann S, Krug CB, Esler KJ, Reisch C, Poschlod P. Pioneers and perches: promising restoration methods for degraded renosterveld habitats? Restoration Ecology 2012; 20(1): 18-23. 10.1111/j.1526100X.2011.00842.x

Holl KD. Do bird perching structures elevate seed rain and seedling establishment in abandoned tropical pasture? Restoration Ecology 1998; 6(3): 253-261. 10.1046/j.1526-100X.1998.00638.x

Howe HF, Smallwood J. Ecology of seed dispersal. Annual Review of Ecology and Systematics 1982; 13(1): 201-228. 10.1146/annurev. es.13.110182.001221

Instituto Brasileiro do Meio Ambiente e dos Recursos Naturais Renováveis - IBAMA. Manual de recuperação de áreas degradadas pela mineração: técnicas de revegetação. Brasília, DF; 1990.

Kageyama PY, Oliveira RE, Moraes LFD, Engel VL, Gandara FB, editors. Restauração ecológica de ecossistemas naturais. Botucatu: Fepaf; 2008.

Lamb D, Erskine PD, Parrotta JA. Restoration of degraded tropical forests landscapes. Science 2005; 310(5754): 1628-1632. 10.1126/ science. 1111773

Laurance WF. Conserving the hottest of the hotspots. Biological Conservation 2009; 142(6): 1137. 10.1016/j.biocon.2008.10.011

Martins SV. Recuperação de áreas degradadas: ações em áreas de preservação permanente, voçorocas, taludes rodoviários e de mineração. 3rd ed. Viçosa: Aprenda Fácil; 2013.

Melo ACG, Durigan G. Evolução estrutural de reflorestamentos de restauração de matas ciliares no Médio Vale do Paranapanema. Scientia Forestalis 2007; (73): 101-111.

Mittermeier RA, Gil PR, Hoffman M, Pilgrim J, Brooks T, Mittermeier $\mathrm{CG}$ et al., editors. Hotspots revisited: Earth's biologically richest and most endangered terrestrial ecoregions. Mexico, DF: Cemex; 2004.

Moraes LFD, Campello EFC, Franco AA. Restauração florestal: do diagnóstico de degradação ao uso de indicadores ecológicos para o monitoramento das ações. Oecologia Australis 2010; 14(2): 437-451. 10.4257/oeco.2010.1402.07

Moro MF, Souza VC, Oliveira-Filho AT, Queiroz LP, Fraga CN, Rodal MJN, Araújo FS, Martins FR. Alienígenas na sala: o que fazer com espécies exóticas em trabalhos de taxonomia, florística e fitossociologia? Acta Botanica Brasilica 2012; 26(4): 991-999. 10.1590/S0102-33062012000400029 
Muler AH. Avaliação de uma floresta atlântica urbana em restauração: da ecologia às questões sociais [thesis]. Rio de Janeiro: Escola Nacional de Botânica Tropical; 2014.

Myers N, Mittermeier RA, Mittermeier CG, Fonseca GAB, Kent J. Biodiversity hotspots for conservation priorities. Nature 2000; 403: 853-858. 10.1038/35002501

Oliveira JC, Salomão TA, Ruggiero C, Rossini AC. Observações sobre o cultivo de Passiflora alata Ait. (maracujá Guaçu). Revista Brasileira de Fruticultura 1980; 2(1): 59-63.

Parker VT. The scale of successional models and restoration objectives. Restoration Ecology 1997; 5(4): 301-306. 10.1046/j.1526100X.1997.00031.x

Parrini R, Pacheco JF, Frugivoria por aves em seis espécies arbóreas do gênero Miconia (Melastomataceae) na Mata Atlântica do Parque Nacional da Serra dos Órgãos, Região Sudeste do Brasil. Atualidades Ornitológicas 2011; (159): 51-58.

Pillatt N, Pillatt N, Franco ETHF, Coelho GC. Dry artificial perches and the seed rain in a subtropical riparian forest. Brazilian Journal of Biosciences 2010; 8(3): 246-252.

Radford AE, Dickinson WC, Massey JR, Bell CR. Vascular plant systematics. New York: Harper \& Row; 1974.

Reid JL, Holl KD. Arrival $\neq$ survival. Restoration Ecology 2013; 21: 153-155. 10.1111/j.1526-100X.2012.00922.x

Reis A, Bechara FC, Espíndola MB, Vieira NK, Souza LL. Restauração de áreas degradadas: a nucleação como base para incrementar os processos sucessionais. Natureza e Conservação 2003; 1(1): 28-36.

Ribeiro MC, Metzger JP, Martensen AC, Ponzoni FJ, Hirota MM. The Brazilian Atlantic forest: how much is left, and how is the remaining forest distributed? Implications for conservation. Biological Conservation 2009; 142(6): 1141-1153. 10.1016/j.biocon.2009.02.021

Rio de Janeiro. Secretaria Municipal do Meio Ambiente. Espécies ameaçadas de extinção no município do Rio de Janeiro. Rio de Janeiro: Flora e Fauna; 2000.

Sansevero JBB, Prieto PV, Sánchez-Tapia A, Braga JMA, Rodrigues PJFP. Past land-use and ecological resilience in a lowland Brazilian Atlantic forest: implications for passive restoration. New Forests 2017; 48(5): 573-586. 10.1007/s11056-017-9586-4

Silva-Weber AJC, Nogueira AC, Carpanezzi AA, Galvão F, Weber SH. Composição florística e distribuição sazonal do banco de sementes em floresta ombrófila mista aluvial, Araucária, PR. Pesquisa Florestal Brasileira 2012; 32(70): 193-207. 10.4336/2012.pfb.32.70.77

Shiels AB, Walker LR. Bird perches increase forest seeds on Puerto Rican landslides. Restoration Ecology 2003; 11(4): 457-465.

Society for Ecological Restoration - SER. The SER primer in ecological restoration: version 2 [Internet]. 2004 [cited 2017 Nov. 14]. Available from: https://bit.ly/2QeOyBv
SOS Mata Atlântica, Instituto Nacional de Pesquisas Espaciais Inpe. Atlas dos remanescentes florestais da mata atlântica: período 2016-2017 [Internet]. São Paulo; 2018 [cited 2018 Nov. 14]. Available from: https://bit.ly/3cWyZIm

Statsoft. Statistica 7.0 [CD-ROM]. Tulsa; 2004.

Stiles EW, White DW. Seed deposition patterns: influence of season, nutrients, and vegetation structure. In: Estrada A, Fleming TF, editors. Frugivores and seed dispersal. Dordrecht: Springer; 1986. p. $45-54$.

Togashi HF, Montezuma CM, Leite AF. Precipitação incidente e fluxo de atravessamento das chuvas em três estágios sucessionais de floresta atlântica no maciço da Pedra Branca, Rio de Janeiro. Revista Árvore 2012; 36(5): 907-917. 10.1590/S0100-67622012000500013

Tomazi AL, Castellani TT. Artificial perches and solarization for restoration: assessment of their value. Tropical Conservation Science 2016; 9(2): 809-831. 10.1177/194008291600900215

Tomazi AL, Zimmermann CE, Laps RR. Poleiros artificiais como modelo de nucleação para a restauração de ambientes ciliares: caracterização da chuva de sementes e regeneração natural. Biotemas 2010; 23(3): 125-135.

Tres DR, Reis A. Técnicas nucleadoras na restauração de floresta ribeirinha em área de floresta ombrófila mista. Biotemas 2009; 22(4): 59-71. 10.5007/2175-7925.2009v22n4p59

Van der Pijl L. Principles of dispersal in higher plants. 3rd ed. Berlin: Springer-Verlag; 1982. 10.1007/978-3-642-87925-8

Veloso HP, Rangel Filho ALR, Lima JCA. Classificação da vegetação brasileira, adaptada a um sistema universal. Rio de Janeiro: IBGE; 1991.

Vicente R, Martins R, Zocche JJ, Harter-Marques B. Seed dispersal by birds on artificial perches in reclaimed areas after surface cool mining Sideropolis municipality, Santa Catarina state, Brazil. Brazilian Journal of Biosciences 2010; 8(1): 14-23.

Whitmore TC. Tropical rain forest dynamics and its implications for management. In: Gómez-Pompa A, Whitmore TC, Hadley M, editors. Forest regeneration and management. New York: Blackwell; 1990. p. 67-89.

Yarranton GA, Morrison RG. Spatial dynamics of a primary succession: nucleation. Journal of Ecology 1974; 62(2): 417-428. $10.2307 / 2258988$

Zucchi MI, Sujii PS, Mori GM, Viana JPG, Grando C, Silvestre EA et al. Genetic diversity of reintroduced tree populations in restoration plantations of the Brazilian Atlantic forest. Restoration Ecology 2017; 26(4): 694-701. 10.1111/rec.12620

Zwiener VP, Cardoso FCG, Padial AA, Marques MCM. Disentangling the effects of facilitation on restoration of the Atlantic forest. Basic and Applied Ecology 2014; 15(1): 34-41. 10.1016/j.baae.2013.11.005 